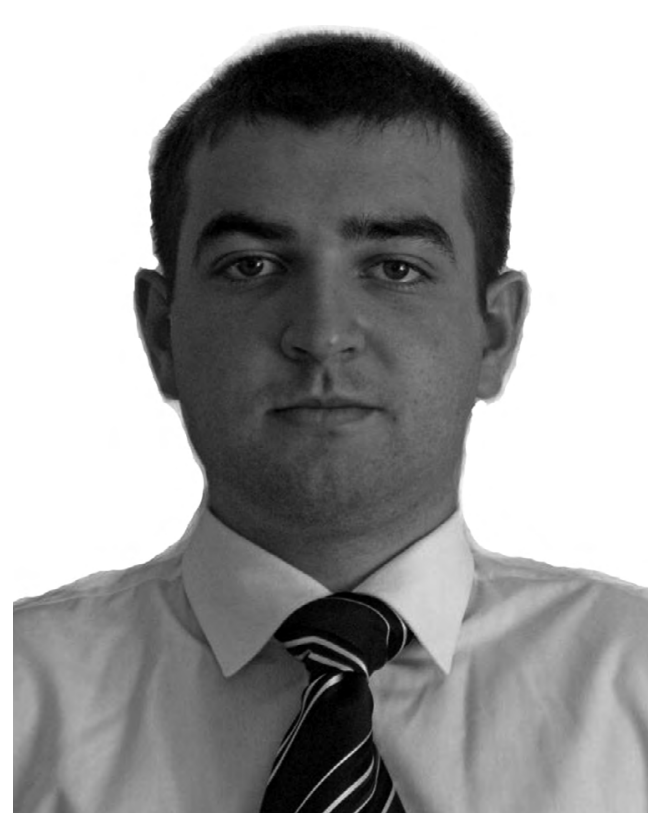

UDC: 338.43.02:636 (477) "71"

Lavruk Alexander Valerievich, doctoral student of the Department of Public Administration, Interregional Academy of Personnel Management, 03039, Kyiv, Str. Frometivska, 2, tel.: (067) 46597 25, e-mail: arhangelprime@gmail.com

ORCID: 0000-0002-7932-0036

\section{Лаврук Олександр Валерійович,} докторант кафедри публічного адміністрування, Міжрегіональна Академія управління персоналом, 03039, м. Київ, вул. Фрометівська, 2, тел.: (067) 46597 25,e-mail: arhangelprime@gmail.com

ORCID: 0000-0002-7932-0036

\section{Лаврук Александр Валериевич,}

докторант кафедры публичного администрирования, Межрегиональная Академия управления персоналом, 03039, 2. Киев, вул.Фрометовская, 2, тел.: (067) 46597 25, e-mail: arhangelprime@gmail.com

ORCID: 0000-0002-7932-0036

DOI https://doi.org/10.32689/2617-2224-2019-16-1-72-81

\title{
STATE POLICY IN THE DEVELOPMENT OF ANIMAL HUSBANDRY IN UKRAINE
}

Abstract. Attention is focused on the relevance of the issue of accelerated political level of development of the state, updating the priorities and values of the political culture of the population of Ukraine. Typically, such innovation processes require the formation of new tasks of state policy in agricultural production. Research is based on the use of information resources, generalization of scientific developments of domestic and foreign scientists, personal observations. The purpose of the article is to determine the essence and theoretical approaches to the formation and implementation of state policy in the development of the livestock industry. The necessity of overcoming the crisis phenomena in animal husbandry, one of the leading branches of economic growth of production, requiring the appropriate influence of the state through the formation of public administration and the implementation of effective public policy. The essence of the state policy is defined, which is a set of forms, methods, principles and tools by which the state provides influence on the activities of livestock enterprises and the functioning of the market of livestock products.

It is proved that one of the directions of the state policy is the expansion of opportunities for livestock use of modern technologies for the production of new 
types of high-quality livestock products. It is established that not only the socioeconomic development of the state, but also the level of its food security depends on the existing problems in animal husbandry. Therefore, the state policy, with the help of the adopted state and political decisions, should regulate the constantly emerging human needs in animal products with the possibility of the state and society to meet them. Accordingly, the need to direct public policy measures to improve state support, which provides for the implementation, through funding from the state budget, innovative renovation and regulation of production activities of livestock enterprises. It is proposed to the Ministry of agrarian policy of Ukraine to develop measures of scientifically sound and effective state policy, which would ensure the development of competitive livestock in the domestic and foreign markets.

Keywords: country, public policy, animal husbandry, public administration, animal products, population, food security.

\section{ДЕРЖАВНА ПОЛІТИКА У РОЗВИТКУ ТВАРИННИЦТВА УКРАЇНИ}

Анотація. Акцентується увага на актуальності питання прискореного рівня політичного розвитку держави, оновлення пріоритетів та цінностей політичної культури населення України. Зазвичай такі інноваційні процеси потребують формування нових завдань перед державною політикою в аграрному виробництві. Дослідження базуються на використанні інформаційних ресурсів, узагальненні наукових розробок вітчизняних і закордонних вчених, особистих спостереженнях. Зазначено необхідність подолання кризових явищ у тваринництві, як однієї з провідних галузей економічного зростання виробництва, які потребують відповідного впливу держави шляхом формування системи державного управління та реалізації ефективної державної політики. Визначено сутність державної політики, що являє собою сукупність форм, методів, принципів та інструментів, за допомогою яких держава впливає на діяльність тваринницьких підприємств та на функціонування ринку тваринницької продукції.

Доведено, що одним з напрямів державної політики є розширення можливостей тваринництва для використання сучасних технологій з метою виробництва нових видів високоякісної тваринницької продукції. Встановлено, що від існуючих проблем у тваринництві залежить не тільки соціально-економічний розвиток держави, але й рівень їі продовольчої безпеки. А тому державна політика за допомогою ухвалених державно-політичних рішень, повинна регулювати постійно виникаючі людські потреби у продуктах тваринного походження з можливістю держави і суспільства їх задовольняти. Відповідно вказується на необхідність спрямування заходів державної політики на покращення державної підтримки, яка передбачає здійснення, за рахунок фінансування із державного бюджету, інноваційного оновлення і регулювання виробничої діяльності тваринницьких підприємств. Запропоновано Міністерству аграрної політики України розробити заходи науково 
обгрунтованої та ефективної державної політики, яка б забезпечила розвиток конкурентоспроможного тваринництва на внутрішньому та зовнішньому ринках.

Ключові слова: держава, державна політика, тваринництво, державне управління, тваринницька продукція, населення, продовольча безпека.

\section{ГОСУДАРСТВЕННАЯ ПОЛИТИКА В РАЗВИТИИ ЖИВОТНОВОДСТВА УКРАИНЫ}

Аннотация. Акцентируется внимание на актуальность вопроса ускоренного уровня политического развития государства, обновления приоритетов и ценностей политической культуры населения Украины. Обычно такие инновационные процессы требуют формирования новых задач перед государственной политикой в аграрном производстве. Исследования базируются на использовании информационных ресурсов, обобщении научных разработок отечественных и зарубежных ученых, личных наблюдениях. Указывается на необходимость преодоления кризисных явлений в животноводстве, одной из ведущих отраслей экономического роста производства, которые требуют соответствующего влияния государства путем формирования системы государственного управления и реализации эффективной государственной политики. Определена сущность государственной политики, представляющая собой совокупность форм, методов, принципов и инструментов, при помощи которых государство обеспечивает влияние на деятельность животноводческих предприятий и на функционирование рынка животноводческой продукции.

Доказано, что одним из направлений государственной политики является расширение возможностей животноводства для использования современных технологий с целью производства новых видов высококачественной животноводческой продукции. Установлено, что от существующих проблем животноводства зависит не только социально-экономическое развитие государства, но и уровень его продовольственной безопасности. Поэтому государственная политика, при помощи принятых государственно-политических решений, должна урегулировать постоянно возникающие человеческие потребности в продуктах животного происхождения с возможностью государства и общества их удовлетворять. Соответственно указывается на необходимость направления мероприятий государственной политики на улучшение государственной поддержки, которая предусматривает осуществление, за счет финансирования из государственного бюджета, инновационного обновления и регулирования производственной деятельности животноводческих предприятий. Предложено Министерству аграрной политики Украины разработать меры научно обоснованной и эффективной государственной политики, которая бы обеспечила развитие конкурентоспособного животноводства на внутреннем и внешнем рынках.

Ключевые слова: государство, государственная политика, животноводство, государственное управление, животноводческая продукция, населения, продовольственная безопасность. 
Problem statement. The current crisis state of agriculture in Ukraine requires the intervention of the state in order to develop public policy measures (formed and implemented in complex internal and external economic and socio-political conditions) and their target direction to overcome the complex, destructive processes in the production and economic activities, which provides an increase in agricultural production. The development of animal husbandry in the country is characterized by an annual reduction in the size of production and livestock of farm animals, poor financial and economic situation of livestock enterprises, reducing their investment attractiveness, constant aggravation of competition, violation of production relations between producers, processors of livestock products and trade structures. Undoubtedly, now the country does not help much in this direction of agricultural activity, and therefore the presence of a proper state policy of the country would not lead to such a deplorable state of the livestock industry.

In most cases, the lack of budgetary funds encourages the allocation of financial resources for the further development of strategic industries such as pig, poultry, which provide accelerated growth of livestock production and maximum profits. At the same time, the development of meat and dairy cattle breeding, sheep breeding, rabbit breeding, is gradually declining, while without them and many other industries, it is difficult to ensure positive changes in the standard of living of the population and meet its food needs. All this requires state intervention in the current situation in order to monitor and find effective management measures to improve the development of production, integration and innovation processes and economic relations between livestock enterprises. Only the responsibility of the authorities and effective state policy can ensure high social development, food security, economic and social stability in the country.

Analysis of recent publications on research issues. The problem of public policy and the analysis of the application of its methods and tools were studied by foreign scientists: D. Anderson, T. Brus, M. Broyn, D. Weimer, E. Vedung, T. Dai, V. Dunn, and others.

Theoretical and methodological analysis, strategies of state policy, mechanisms of its implementation and management decision-making were devoted by such domestic scientists as V. Bakumenko, A. Valevsky, Z. Varnaly, V. Vorotin, V. Goshovsky, A. Kilievich, M. Latinin, V. Mamonov, P. Mironenko. Romanov, V. Tertychka and many other scientists.

However, quite a lot of scientific and theoretical questions regarding the definition of the nature, characteristics, goals, regulators of strategies, development programs and mechanisms for the implementation of effective public policy and management decisions on the further development of animal husbandry are still insufficiently investigated.

Purpose of the article. The purpose of the article is to determine the essence and theoretical approaches to the formation and implementation of state policy in the development of animal husbandry.

Presenting the main material of research. Studies have shown that cur- 
rently the main problem of livestock farming is the lack of interest of the state to increase the number of livestock of farm animals (for 2000-2016. the number of cattle in all categories of farms decreased by $60.9 \%$, pigs - by $12.8 \%$, sheep and goats - by $29.9 \%$ ) and the motivation of business structures to increase the volume of animal husbandry production. In this situation, it is advisable to form effective options for the choice of alternative parameters of state policy in the interpretation of targeted state political and administrative measures, management tools (legal basis of state management actions) and resources (administrative, material, financial, information, human and political opportunities) for the timely adoption of state decisions on the further development of animal husbandry.

Usually now it is almost impossible to ensure the rapid restoration of the achieved milestones in the development of animal husbandry, especially in a certain sequence of agricultural programs developed by the state (State support for the livestock industry and support for the maintenance of young cattle), Cabinet of Ministers resolutions on approval of the procedure for the use of funds provided in the state budget to support the livestock industry, laws of Ukraine (on milk and dairy products, on breeding in animal husbandry, on veterinary medicine) and other normative legal acts on animal husbandry, which do not take into account unstable political and complex and unpredictable market situations. This requires a transition to the widespread use of new forms (flexible and optimal combination of mechanisms of state and market regulation) of the impact of public authorities on production and technological processes in the livestock sector, which will ensure its effective functioning and the creation of competitive advantages in world markets.

In the transformation period, when there are big global changes, the state policy, being in the environment of complex political processes, is directed to the effective solution of production and social problems. At the same time, the effective role of the country is aimed at creating favorable economic conditions, and therefore must comply with three basic principles: efficiency, stability, justice [1]. Under these conditions, the state will provide financial assistance to producers of livestock products to facilitate the transfer of livestock to the innovative way of development and industrial basis of the organization of processing and marketing of livestock products [2].

Ensuring the implementation of such processes will be preceded by taking into account the main features of the formation and implementation of public policy: the process of state decision-making is carried out with the participation of various parties (voters, elected officials, civil servants, courts, groups formed by their own interests, public authorities and local self-government) and the administrative apparatus (which includes political and administrative).

In this context, public policy must meet such requirements:

- timely respond to changes that occur in society, the state, the region, as well as in animal husbandry; 
- pay attention and consider the entire list of emerging social and industrial problems and ways to solve them;

- a comprehensive approach to the formation of state-political decisions, the development of appropriate tools and mechanisms for their implementation;

- in any situation, to be effective and have the trust of society and the public.

It should be noted that public policy research provides an opportunity to show the existence of multiple links between different individuals, groups and organizations. In some cases, public policy does not apply to the whole society, but only to the regulation of processes in specific areas of activity or involves the impact on a certain social group. Here we note that the state policy is a purposeful activity of public authorities, aimed at solving a set of interrelated social problems.

Not by chance under the state policy scientists understand "...activities aimed at solving the problems of social development" [3, p. 21]. The same opinion is shared by other researchers who believe that public policy "...includes the definition of the problem, goals and tools to solve the problem" [4, p. 44]. In this case, it is believed that state policy is only a tool, a means to obtain and retain power by certain political forces, but without a clear distribution of tasks, powers and responsibilities of state, executive and local authorities. Individual scientists under the definition of public policy understand "... relatively stable, organized and purposeful activities of the government in relation to a particular problem or subject of consideration, which is car- ried out directly or indirectly through authorized agents and affects the life of the society" [5, p. 12 ].

Public policy is extremely necessary in public life, as it is entrusted with the function of identifying production and social problems that are important to analyze in a timely manner, to establish the causes, complexity and the possibility of timely solutions. Now in the environment of state policy should be taken not only a number of public policy decisions aimed at solving socio-economic problems, but also to develop scientific and strategic programs and determine the tools for their implementation in the animal husbandry. The need for implementation of the state policy is determined by the needs of accelerating the development of animal husbandry on an innovative platform. It is argued that the lack of innovation in agriculture in the development of infrastructure of the agricultural market leads to the lag of Ukraine from the leading countries of Europe and the world [6, p. 68].

State policy is one of the basic components of political and management activities in the livestock sector, it remains the object of influence of society and business structures. In most cases, it is formed in the public sphere of public interests, goals and objectives that are inherent not only in agriculture but also in the livestock sector, and therefore make it possible to form a model (determined by ideological and political imperatives that meet the new conditions and needs of its further development on the basis of which political, legal and managerial decisions are made. Moreover, state policy contributes to the formation of a market 
environment in the animal husbandry, which fully meets the national interests of livestock producers.

But it is very important for the country to guarantee the population's demand for meat and dairy products in order to stabilize the market situation. Otherwise “...the country will not receive the necessary volume of important products of consumption of its own production, which as a result will violate the requirements of food security, increase the risk associated with the lack of food resources" [7, p. 26]. The urgent problems are assigned to the Ministry of agrarian policy and food in terms of the development of various measures to ensure the further development of animal husbandry and increase its competitiveness in the domestic and foreign markets.

For quite a long period of time the state policy was based on the application of command and administrative and bureaucratic methods of management agricultural production, among which an important place was occupied by livestock. Now the main task of the state policy is to provide an indirect, flexible system (inherent in market forms of management) of intervention in production activities and full financial support to improve the investment attractiveness and effective development of the livestock industry. An extremely important aspect is that the country should regulate economic processes, ensure the implementation of socio-economic and legal functions, and the formed state policy should contribute to the formation of relations with livestock producers on the principles of partnership, mutual understanding and observance of business relations in ac- cordance with the economic interests of this sphere of activity.

Taking into account these directions of state policy in the development of animal husbandry will create objective conditions for the growth of incomes and the formation of an adequate standard of living, which will have a positive impact on the process of investing in the formation of qualitative characteristics of livestock workers and the maximum satisfaction of their food needs. In the future, the country should teach livestock farmers to effectively manage in difficult market conditions for the purpose of profitable production of animal husbandry. In addition, the country is obliged to show a caring attitude to livestock workers, while creating a special fund of social guarantees in case of further forced job cuts in the main livestock sub-sectors.

Now there is an active development of civil society institutions, which in most cases affect the legislative processes of public authorities through active public participation in the formation and implementation of public policy [8]. Consequently, the development of public policy, the main task of which is the formation of a mechanism for identifying and ensuring public interests, is intensified. It is associated with the embodiment of power since the formation of various policy problems and promotes the adoption of power political and managerial decisions, for which the necessary tools and mechanisms for their implementation in the implementation of various activities to achieve social goals are selected. Economic entities interested in solving socially 
significant problems may have access to such solutions [9]. According to the publicity policy finds its place where it is aimed at achieving public goals and public interests [10, p. 193].

A particularly important role should be given to the state regional policy, which is able to provide:

- state support and creation of institutional conditions for the development of animal husbandry and food security in each region;

- adoption of state and political decisions to improve the competitiveness of regions by providing them with high-performance genetic potential of farm animals and highly qualified human resources;

- improvement and strengthening of cooperation of regions in the legal, legislative and partner field of relations and the mechanism of their implementation;

- clear legislative distribution of powers and responsibilities between national, regional and local levels of government.

Do not underestimate the importance of scientifically sound and effective public policies for rural development (European values and European practices), since the small and medium producer became her priority. Scientific approaches and models of such policy are still characterized by innovation for the majority of members of society, and therefore require public justification of the problems of development of the main sectors that provide the food problem of the country. Currently, the state policy uses a system of standard methods of legislative, Executive and control nature, often used by the competent state bodies to ensure the effectiveness of socio-economic relations and production processes in the livestock sector.

Conclusions and prospects for further research. Research have shown that public policy is one of the important elements and criteria of society (aimed at improving social stability and living standards of citizens), certain production areas and sectors of activity, in particular livestock (provides the population with food and guarantees food security of the country). Therefore, all aspects (models, institutions, tools, programs, processes of formation and implementation, evaluation and regulation) of public policy are widely and comprehensively studied and interpreted by foreign and domestic scientists in different versions of the presentation. However, in the research of public policy, it is not necessary to give priorities only to the methods and levers of its administrative impact on socioeconomic and political processes, but also to focus on the planning, organization and monitoring of the functions of each of its elements.

In the future, the importance of the study of public policy is not diminished, since it is conditioned by the characteristic features of the demands of society and modern political processes of power and political decisionmaking, which are formed in the environment of the political system. In the context of this, a more in-depth study of the problems of the development and application of state policy not only in various spheres of public life, but also in agriculture and its main sectors, which form the food security of the country, is expected. 


\section{REFERENCES}

1. Samuelson P. (1992), Ekonomika [Economy], NPO Alhon, Moscow, Russia.

2. Kolyadenko S. V. (2011), "Organizational and economic basis of animal products in Ukraine", Stalyi rozvytok ekonomiky, vol. 6, pp. 6-10.

3. Valersky O. L. (2001), Derzhavna polityka v Ukraini: metodolohiia analizu, stratehiia, mekhanizmy vprovadzhennia [State policy in Ukraine: methodology of analysis, strategy, mechanisms of implementation], NISD, Kyiv, Ukraine.

4. Bazhal J. Kilievich O. and Mertens $O$. (2001), Ekonomichnyi rozvytok i derzhavna polityka [Economic development and public policy], Vydavnytstvo UADU, Kyiv, Ukraine.

5. Romanov V. Ye. Rudik, O. M. and Brus T. M. (2003), Derzhavna polityka: analiz ta mekhanizmy yii vprovadzhennia [Public policy: analysis and mechanisms of its implementation], DRIDU NADU, Dnipro, Ukraine.

6. Tulchynska S. O. and Kirichenko S. O. (2017), "Research of methodological approaches to assessing the development of social infrastructure in the regions", Ekonomichnyi visnyk NTUU "KPI", vol. 14, pp. 67-74.

7. Misyuk M. V. (2012), Rynok produktsii skotarstva [The market of livestock products], NNTs "IAE", Kyiv, Ukraine.

8. Cabinet of Ministers of Ukraine (2015), "Resolution of the Cabinet of Ministers of Ukraine "Ensuring public participation in the formation and implementation of state policy", available at: http://zakon.rada.gov.ua (Accessed 06 October 2018).

9. Open eyes (2014), Sitnik, S.V. "Political aspects of norm-setting organization in Ukraine", available at: http:// www.vidkryti-ochi.org.ua/2014/11/ blog-post.html (Accessed 06 October 2018)

10. Teleshun S. Sitnik, S. and Reiterovich I. (2012), "Public or public policy-domestic dilemma of choice", Bulletin of The national Academy of public administration under the President of Ukraine, Vol. 4, available at: http:// nbuv.gov.ua/UJRN/Vnadu 2012_4_25 (Accessed 06 October 2018).

\section{СПИСОК ВИКОРИСТАНИХ ДЖЕРЕЛ}

1. Самуельсон П. Экономика: в 2 т.: пер. с англ. / П. Самуельсон. М.: НПО Алгон, 1992. Т. 1.510 с.

2. Коляденко С. В. Організаційно-економічні засади тваринницької продукції в Україні/ Сталий розвиток економіки. 2011. № 6. С. 6-10.

3. Валевський О. Л. Державна політика в Україні: методологія аналізу, стратегія, механізми впровадження: [монографія]. - К.: НІСД, 2001. 242 с.

4. Бажал Ю., Кілієвич О., Мертенс О. та ін. Економічний розвиток і державна політика: [навч. посіб.]. К.: Вид-во УАДУ, 2001. 480 с.

5. Романов В. С., Рудік О. М., Брус Т. М. Державна політика: аналіз та механізми iї впровадження. - Дніпро: ДРІДУ НАДУ, 2003. $72 \mathrm{c.}$

6. Тульчинська С. О. Дослідження методичних підходів оцінки розвитку соціальної інфраструктури в регіонах / С. О. Тульчинська, С. О. Кириченко // Економічний вісник НТУУ “КПІ". Вип. 14. К.: Політехніка, 2017. С. 67-74.

7. Місюк М. В. Ринок продукції скотарства: монографія. К.: ННЦ "ІАЕ", 2012. $330 \mathrm{c}$.

8. Постанова Кабінету Міністрів України "Про забезпечення участі громадськості у формуванні та реалізації державної політики" 
[Електронний ресурс]. Режим доступу: http:zakon3.rada.gov.ua/laws/ show/996-2010-\%D0\%BF

9. Ситник С. В. Політичні аспекти організації нормотворчості в Україні // Відкриті очі. 2014 [Електронний ресурс]. Режим доступу: http://www.vidkryti-ochi.org. ua/2014/11/blog-post.html
10. Телешун С., Ситник С., Рейтерович I. Публічна чи державна політика вітчизняна дилема вибору. Вісник Національної академії державного управління при Президентові України. 2012. Вип. 4. С. 185-196 [Електронний ресурс]. Режим доступу: http://nbuv.gov.ua/UJRN/ Vnadu_2012_4_25 